US\$750 million to send military personnel and other resources to the outbreak zone.

Funding for many science agencies did rise slightly overall in the 2014 fiscal year after the mandatory sequestration in 2013. The National Oceanic and Atmospheric Administration's budget actually rose by roughly $\$ 575$ million in 2014 , to $\$ 5.3$ billion. But the National Institutes of Health (NIH), the world's largest biomedical-research funder, received $\$ 29.9$ billion, less than its pre-sequester budget of $\$ 30.7$ billion.

"Everybody in Congress knows that science is important," says Congressman Rush Holt (Democrat, New Jersey), "but they don't have much appreciation of what it takes to sustain it." (Physicist Holt, one of the few scientists in US public office, famously gives out bumper stickers that read, "My Congressman IS a Rocket Scientist!”)

The NIH cuts have put the squeeze on many research institutions. At the Washington University School of Medicine in St Louis, Missouri, for example, federal grant funding fell by $14 \%$ from fiscal year 2012 to 2013, and by another 3\% from 2013 to 2014. "Part of it was sequestration, part of it was the timing of some big grants expiring," says Jennifer Lodge, the university's vicechancellor for research. "It sort of reeks of an atmosphere of gloom around funding."

The story is similar at the University of Arizona in Tucson, which relies heavily on support from the NIH and NASA. Although the university has begun seeking more funding from industry and philanthropists, "there's still a sense of unease about what the future looks like", says Kimberly Andrews Espy, the university's senior vice-president for research.

Others are more optimistic. The University of Maryland in College Park saw its share of federal grants rebound in the 2013-14 academic year, rising nearly 3\% on the year before. Its chief research officer Patrick O'Shea says that success in chasing large awards has helped his institution to prosper as federal budgets have grown tighter. "Rather than complaining, we're trying to be more effective," he says.

Beyond the coming election, US policy analysts are already looking to another, key political test: whether lawmakers will finalize a 2015 budget deal before they depart for the year in late November. Jennifer Zeitzer, deputy director of public affairs at the Federation of American Societies for Experimental Biology in Bethesda, Maryland, sees signs of a "good-faith effort" to approve a spending deal in the next several weeks.

But even if the lawmakers deliver, she says, that will not make up for four years of legislative torpor. "This Congress was so spectacularly unproductive," she says, "that even showing up will give the next Congress a leg up." -

PALAEOANTHROPOLOGY

\title{
Oldest-known human genome sequenced
}

\section{DNA shows a group of modern humans roamed across Asia.}

\section{BY EWEN CALLAWAY}

$\Delta$ 45,000-year-old leg bone from Siberia has yielded the oldest genome sequence for Homo sapiens on record - revealing a mysterious population that may once have spanned northern Asia. The DNA sequence from a male hunter-gatherer also offers tantalizing clues about modern humans' journey from Africa to Europe, Asia and beyond, as well as their sexual encounters with Neanderthals.

His kind might have remained unknown were it not for Nikolai Peristov, a Russian artist who carves jewellery from ancient mammoth tusks. In 2008, Peristov was looking for ivory along Siberia’s Irtysh River when he noticed a bone jutting from the riverbank. He dug it out and showed it to a police forensic scientist, who identified it as probably human.

The bone turned out to be a human left femur, and eventually made it to the Max Planck Institute for Evolutionary Anthropology in Leipzig, Germany, where researchers carbondated it. "It was quite fossilized, and the hope was that it might turn out old. We hit the jackpot," says Bence Viola, a palaeoanthropologist who co-led the study of the remains. "It was older than any other modern human yet dated." The luck continued when Viola's colleagues found that the bone contained well-preserved DNA, and they sequenced its genome to the same accuracy as that achieved for contemporary human genomes (Q. Fu et al. Nature 514, 445-449; 2014).

The researchers named their find Ust'-Ishim, after the district where Peristov found the remains. They dated him to between 43,000 and 47,000 years old, nearly twice the age of the nextoldest known complete modernhuman genome, although older, archaic-human genomes exist.

DNA may be the only chance to connect the remains to other humans. "This guy came out of nowhere there's no archaeology site we could connect it to," says Viola, suggesting that his group roamed far and wide.

The Ust'-Ishim man was probably descended from an extinct group that is closely related to humans who left Africa more than 50,000 years ago to The Ust'-Ishim populate the rest of the femur. world, but later went extinct, Viola says.

The most intriguing clue about his origin is that about $2 \%$ of his genome comes from Neanderthals. This is roughly the same level that lurks in the genomes of all of today's nonAfricans, owing to ancient trysts between their ancestors and Neanderthals. The Ust'-Ishim man probably got his Neanderthal DNA from these same matings, which, past studies suggest, happened after the common ancestor of Europeans and Asians left Africa and encountered Neanderthals in the Middle East.

Until now, the timing of this interbreeding was uncertain - dated to between 37,000 and 86,000 years ago. But Neanderthal DNA in the Ust'-Ishim genome pinpoints it to between 50,000 and 60,000 years ago on the basis of the long Neanderthal DNA segments in the Ust'-Ishim man's genome. Paternal and maternal chromosomes are shuffled together in each generation, so that over time the DNA segments from any individual become shorter.

The more precise dates for Neanderthalhuman mating pose a challenge for scientists who have proposed that modern humans left Africa before 100,000 years ago and reached Asia more than 75,000 years ago, says Chris Stringer, a palaeoanthropologist at London's Natural History Museum. Those researchers, who include Michael Petraglia, an archaeologist at the University of Oxford, UK, have pointed to $H$. sapiens-like bones from the Levant that are older than 100,000 years and to 70,000-year-old stone tools found in India as evidence for an early human exodus to Asia along a southern coastal route that eventually reached Oceania and Australia.

But Petraglia sees Ust'-Ishim's genome differently. "I think this is part of a population boom that's going on around 45,000 years ago, which means modern humans got to the ends of the world by 45,000 years ago," he says. Their numbers might have swamped human populations that arrived in earlier migrations.

Petraglia expects that ancient DNA and other fossil finds will paint a much more complicated picture of the peopling of Asia. "This is just a random find in a Siberian river deposit," Stringer says. "What else could be there when they start looking systematically?" 